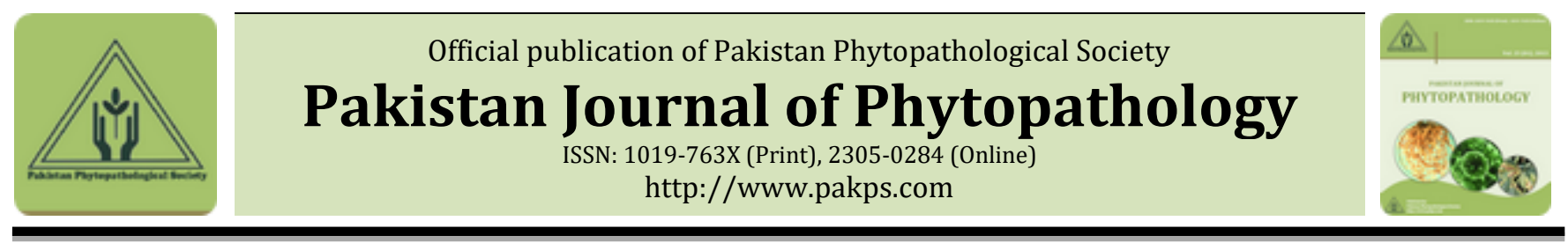

\title{
PLANT PARASITIC NEMATODE OF GENERA APHELENCHUS AND APHELENCHOIDES (NEMATODA: APHELENCHOIDEA) FROM DISTRICT LAKKI MARWAT, KHYBER PAKHTUNKHWA, PAKISTAN
}

\author{
Samreen Khan*, Salma Javed, Tabassum A. Khanum \\ National Nematological Research Centre, University of Karachi, Karachi-75270, Pakistan.
}

A B S T R A C T

\begin{abstract}
The research work is based on the study regarding nematodes belonging to the order of Aphelenchida. Research work was carried out in four sites of District Lakki Marwat, Khyber Pakhtunkhwa Pakistan, where no such research was conducted about nematode fauna presence in the past. For the said purpose, numbers of soil samples from different rhizosphere were collected from various sites in the year 2019. Upon completion of all pre-requisite, the related correspondence and data of the surveyed sites with their results including, occurrence percentage, Relative Frequency, Simpson Diversity Index and Dendrogram of Cluster Analysis were ensured. However, detailed analysis revealed two types of genera i.e Aphelenchus (49\%) while Aphelenchoides (51\%). Resultantly, two species of Aphelenchus namely Aphelenchus avenae and Aphelenchus isomerus; while four species of Aphelenchoides namely Aphelenchoides bicaudatus,Aphelenchoides richardsoni, Aphelenchoides unisexus and Aphelenchoides macrospica were surfaced. The Aphelenchus avenae was found most frequently abundance species (40\%) from all sites and followed by Aphelenchoides richardsoni (20\%). The highest abundance occurrence site of both genera was village Aba Khel (50\% each) and the lowest one village Aghzar Khel Aphelenchus (22.7\%) and Aphelenchoides (18.1\%). All these species were previously reported for Pakistani nematode fauna except Aphelenchoides macrospica which was surfaced for the first time from Pakistan. It is also pertinent to mentioned here that remaining species were surfaced from new host and location from Pakistan.
\end{abstract}

Keywords: Aphelenchus, Aphelenchoides, District Lakki Marwat, New record, New host and locality.

\section{INTRODUCTION}

Lakki Marwat is one of the Southern Districts of Khyber Pakhtunkhwa Province, Pakistan and located at $32^{\circ} 17^{\prime}-$ $32^{\circ} 53^{\prime} \mathrm{N}$ Latitude and $70^{\circ} 23^{\prime}-71^{\circ} 16^{\prime}$ E Longitude. Total area covered of 3,164 Square kilometers (ESA, 2012) and having population of 876,182 as per last census conducted in year 2017. On the North side covered by District Bannu and District Karak while on the East side bounded by District Mianwali, Punjab. Towards South East of the District Dera Ismail Khan while southwest covered by the District Tank. On the western side joined by the tribal areas of District Tank including some areas

Submitted: August 20, 2020

Revised: October 08, 2020

Accepted for Publication: October 21, 2020

* Corresponding Author:

Email: samreenkhan3336@gmail.com

(C) 2017 Pak. J. Phytopathol. All rights reserved. of South Waziristan Agency. Region of district Lakki Marwat has all the characteristics of a desert due to its sand dunes, scorching heat and dry weather with hot summers and moderately cool winters. However, rainfall is very rare and intermittent and generally arises in July and August. The component elements of the area's soils are extremely and deeply drained, calcareous and uneven surfaced and likewise loamy sand. The fine textured soils are sandy clay and clay loam of the area and contained variety of rocks of Bhittani and Waziristan ranges. Climate of the area is arid to semi arid and sub-tropical continental. Variation in temperature scale commonly noted during the summer season from $27-42^{\circ} \mathrm{C}$ and in winter season from $4-20^{\circ} \mathrm{C}$ (Haq, 2009). Geography of the region is a mixture of hills and sandy plains. Maximum boundaries of the district contained on hills including East, Southeast, Southwest as well as Northwest. General dimension and elevation 
of these hills ranging from 500 to 1000 meters and most of the district region is almost shown 200 to 300 meters above level of sea.

Most of region consists on arid plains and required a lot number of sources which is appropriate and commonly considered fruitful for the development of agriculture field. However, the area unfortunately facing acute shortage in constraints i.e. shortage of water and nonexistence of irrigation system due to which the land is extremely weak for agriculture purpose (ESA, 2012). Lakki Marwat area is not rich with any sources to highlight but entirely depends upon rain water. The two prominent crops are wheat and gram and mostly the drought has severely affected both crops in the sandy areas of district. These crops have been grown on vast tract of land in the barani (rain fed) belt. The crops especially wheat and gram have been affected due to low perspiration in winter season, which is a major cause of concern for farmers. Other than aforementioned; some other crops are also growing up including maize, rice, Bajra, Jowar (Sorghum), Sugarcane, Gaura, Barley, Rape and Mustard, Masoor, Dates, Orange, Mango, Guava, Watermelon, Melon, Pomegranates, Banana, Grapes, Mulberry and Ber.

The planet earth is engrossed by immense diversity of life and existence of nematodes is the second most species rich phylum next to Arthropoda (Keshari et al., 2019). Nematodes are parasites and microscopic round worms and it may be source of threat to food insecurity in numbers of countries. Nevertheless, Pakistan face the issues of damaging of plants by nematodes due to its geographical location particularly in the sultry areas in which the climate is considered utmost appropriate for reproduction including activities of nematodes all over the year (Maqbool, 1988). The Order Aphelenchida is one of the abstemiously limitless nematodes order which is consists on numbers of ecological sets including fungal feeding, obligate insects' parasites, predator while some of them belongs to phytoparasite related to the genera Bursaphelenchus Fuchs, 1937 and Aphelenchoides Fischer, 1894 (Nickle, 1970), but large number of species of Aphelenchoides are fungal feeder or predators (Kanzaki and Giblin-Davis, 2012). Generally, the Aphelenchus are highly active nematode, predominantly mycetophagous in habit, cosmopolitan in soil, plant debris free-living and association with lichens, on tree bark as well as in the tunnels of wood-boring beetles (Hunt, 1993).
Aphelenchus belong to be genera Aphelenchus and Aphelenchoides are the utmost and widely spread and being primarily mycetophagous almost certainly represent the nearby to the ancestral forms (Hunt, 1993). Although, most Aphelenchoides are entirely mycetophagous, while few species under the sobriquet 'bud and leaf nematodes', parasitize higher plants. However, Aphelenchoides may be retrieved from mosses, soil, decaying organic materials, mushrooms while from plant tissues (Khusainov, 2013). Sanchez-Monge et al., 2015 search out plant parasitic nematodes with presented 13 plant parasites considered most important all over the world.

Currently, nineteen species of genus Aphelenchoides Fischer, 1894 and four species of genus Aphelenchus Bastian, and 1865 has been reported from Pakistan (Shahina et al., 2019). The objective of this plan was to study the Aphelenchid nematodes by conducted nematological survey from different areas of District Lakki Marwat, Khyber Pakhtunkhwa (KPK), and Pakistan.

\section{MATERIALS AND METHODS}

Area of Exploration:Nematological survey was undertaken in the months of October and November 2019 in various sites including villages Aba Khel, Aghzar Khel, Sarai Naurang and Tajori of the District Lakki Marwat, Khyber Pakhtunkhwa, Pakistan. Total 61 soil samples of different plants were retrieved and subsequently these samples were safely brought to laboratory of National Nematological Research Centre, University of Karachi, Pakistan. The aim of said survey was to establish the biodiversity of Aphelenchid nematodes.

Collection and Processing of Soil Sample:The soil samples (500 gm) each from different infected plant host were collected and packed in clean plastic bags, tied up and labeled appropriately containing relevant information i.e. host, locality, time and date of collection and shifted to the laboratory of National Nematological Research Centre, University of Karachi, Pakistan and accordingly stored at $5-10^{\circ} \mathrm{C}$. The nematodes from soil was extracted by means of Cobb's sieving and decanting method (Cobb, 1918) and further purified by Baermann's funnel technique (Baermann, 1917). The extracted nematodes were quantified in a chamber within $5 \mathrm{ml}$ suspension through counter under the binocular microscope and the same procedure was 
repeated 3 times and the average reading result found the number of nematodes as per unit of soil sample. Retrieved nematodes were killed instantaneously by pouring a hot water $\left(80-90^{\circ} \mathrm{C}\right)$ in a glass cavity block and immediately preserve in TAF (Tri-ethanol Amine Formalin) solution for 24 hours (Courtney, Polley and Miller, 1955). After that fixed nematodes were sanitized thrice with distilled water. Specimens were kept for 5-6 days in an incubator at $55^{\circ} \mathrm{C}$ in $2 \mathrm{ml}$ of $1.25 \%$ glycerin for slow dehydration (Seinhorst, 1959). Permanent mounting was done by transferring of nematodes to a clean microscopic glass slide having pure drop of glycerin and sealed with paraffin wax by gently heating the slide. Later on, measurements were undertaken by de Man's, 1884 formula through compound microscope Nikon Eclipse E-400.

\section{DATA ANALYSIS}

The aim of area explored in District Lakki Marwat was to ascertain the existence and percentage of Aphelenchid nematodes. The occurrence percentage and relative frequency of nematodes was assessed as follows:

$$
\begin{gathered}
\text { Occurence }(\%)=\frac{\text { Total number of positive samples }}{\text { Total number of Samples }} \times 100 \\
\text { Relative Frequency }(\%)=\frac{\text { Frequency of Genus/ Species in a sample }}{\text { Sum of frequencies of all genus/ species present }} \times 100
\end{gathered}
$$

Statistically, it was also analyzed by dendrogram of cluster analysis and Simpson diversity index (Simpson, 1949). Diversity index was determined by using the formula as follows:

$$
D=1-\frac{\sum n(n-1)}{N(N-1)}
$$

$\mathrm{D}=$ Diversity, $\mathrm{N}=$ Total number of individuals (Genus), $\mathrm{n}=$ Number of each individual (Particular Genus).

\section{RESULTS}

During the study of nematodes belonging to the order of Aphelenchida, it was revealed that various locations of district had large number of plant-parasitic nematodes genera including Ditylenchus, Tylenchorhynchus, Pratylenchus, Hoplolaimus, Helicotylenchus, root knot nematodes and other free-living soil nematodes. However, special focus was given only on plant parasitic Aphelenchus and Aphelenchoides due scope of work.

Occurrence percentage: 30 soil samples out of 61 were found positive and detailed analysis of overall samples revealed two types of genera i.e Aphelenchus (49\%) as well as Aphelenchoides (51\%). In term of overall occurrence percentage of both genera reported from each site along with Global Positioning System (GPS) was illustrated (Table 1) and earmarked the highest abundance occurrence of both genera in Aba Khel (50\% each) and the lowest occurrence in the village Aghzar Khel Aphelenchus (22.7\%) and Aphelenchoides (18.1\%). Furthermore, occurrence of genus was further probed to ascertain the fact and figure of each genus according to locations where surfaced through applied

\begin{tabular}{|c|c|c|c|c|c|c|c|c|}
\hline Sites & Latitude & Longitude & NS & NPS & Genus & SCG & Occurrence & $\mathrm{RF}$ \\
\hline \multirow[t]{2}{*}{ Aba Khel } & \multirow[t]{2}{*}{$32 \div 34$ '09"N } & \multirow[t]{2}{*}{ 7049'39"E } & \multirow[t]{2}{*}{04} & \multirow[t]{2}{*}{03} & Aphelenchus & 02 & $50 \%$ & 11.7 \\
\hline & & & & & Aphelenchoides & 02 & $50 \%$ & 10.5 \\
\hline \multirow[t]{2}{*}{ Aghzar Khel } & \multirow[t]{2}{*}{$32 \div 23^{\prime} 37^{\prime \prime N}$} & \multirow[t]{2}{*}{$70^{\circ} 44^{\prime} 16 " \mathrm{E}$} & \multirow[t]{2}{*}{22} & \multirow[t]{2}{*}{07} & Aphelenchus & 05 & $22.7 \%$ & 29.4 \\
\hline & & & & & Aphelenchoides & 04 & $18.1 \%$ & 21.0 \\
\hline \multirow[t]{2}{*}{ Sarai Naurang } & \multirow[t]{2}{*}{$32^{\circ} 49^{\prime} 43^{\prime \prime} \mathrm{N}$} & \multirow[t]{2}{*}{$70^{\circ} 46^{\prime} 33^{\prime \prime E}$} & \multirow[t]{2}{*}{29} & \multirow[t]{2}{*}{16} & Aphelenchus & 08 & $27.5 \%$ & 47.0 \\
\hline & & & & & Aphelenchoides & 11 & $37.9 \%$ & 57.8 \\
\hline \multirow[t]{2}{*}{ Tajori } & \multirow[t]{2}{*}{$32 \div 37^{\prime} 51 " \mathrm{~N}$} & \multirow[t]{2}{*}{ 70-34'59"E } & \multirow[t]{2}{*}{6} & \multirow[t]{2}{*}{04} & Aphelenchus & 02 & $33.3 \%$ & 11.7 \\
\hline & & & & & Aphelenchoides & 02 & $33.3 \%$ & 10.5 \\
\hline
\end{tabular}
Relative Frequency (RF).

Table 1. Site Wise Occurrence \% of each Genus Aphelenchus and Aphelenchoides

NS=Number of Samples, NPS=Number of Positive Samples, SCG=Samples Containing Genus, RF=Relative Frequency

Dendrogram: The dendrogram of cluster analysis among the various sites of surveyed areas was applied and accordingly presenting (Figure 1). These locations were divided into two main clades. Sarai Naurang and Tajori has been placed in clade I; while, Aba Khel and Aghzar Khel formed clade II. In the same context, cluster analysis of six nematodes species including Aphelenchus avenae and Aphelenchoides richardsoni formed clade I; while, Aphelenchusisomerus, Aphelenchoides bicaudatus, Aphelenchoides macrospica and Aphelenchoides unisexus form clade II (Figure 2). 


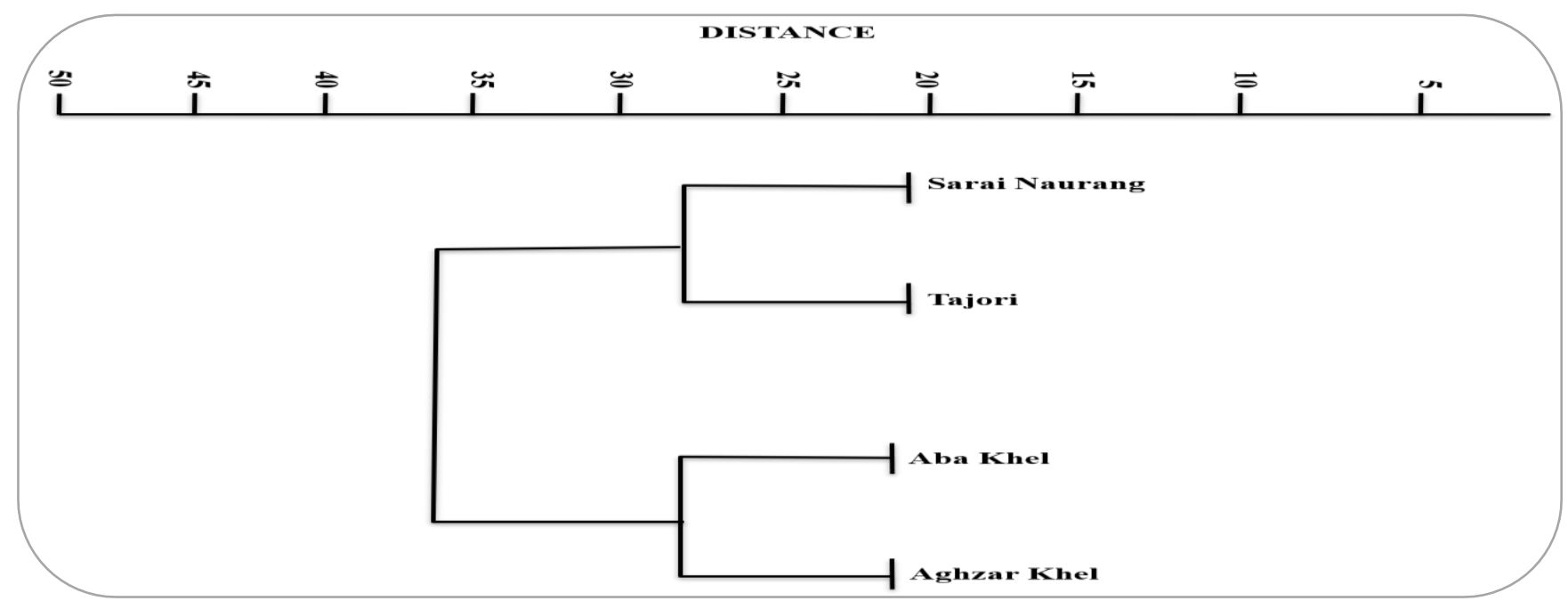

Figure 1. Dendogram resulting from the average linkage of 04 sites of District Lakki Marwat
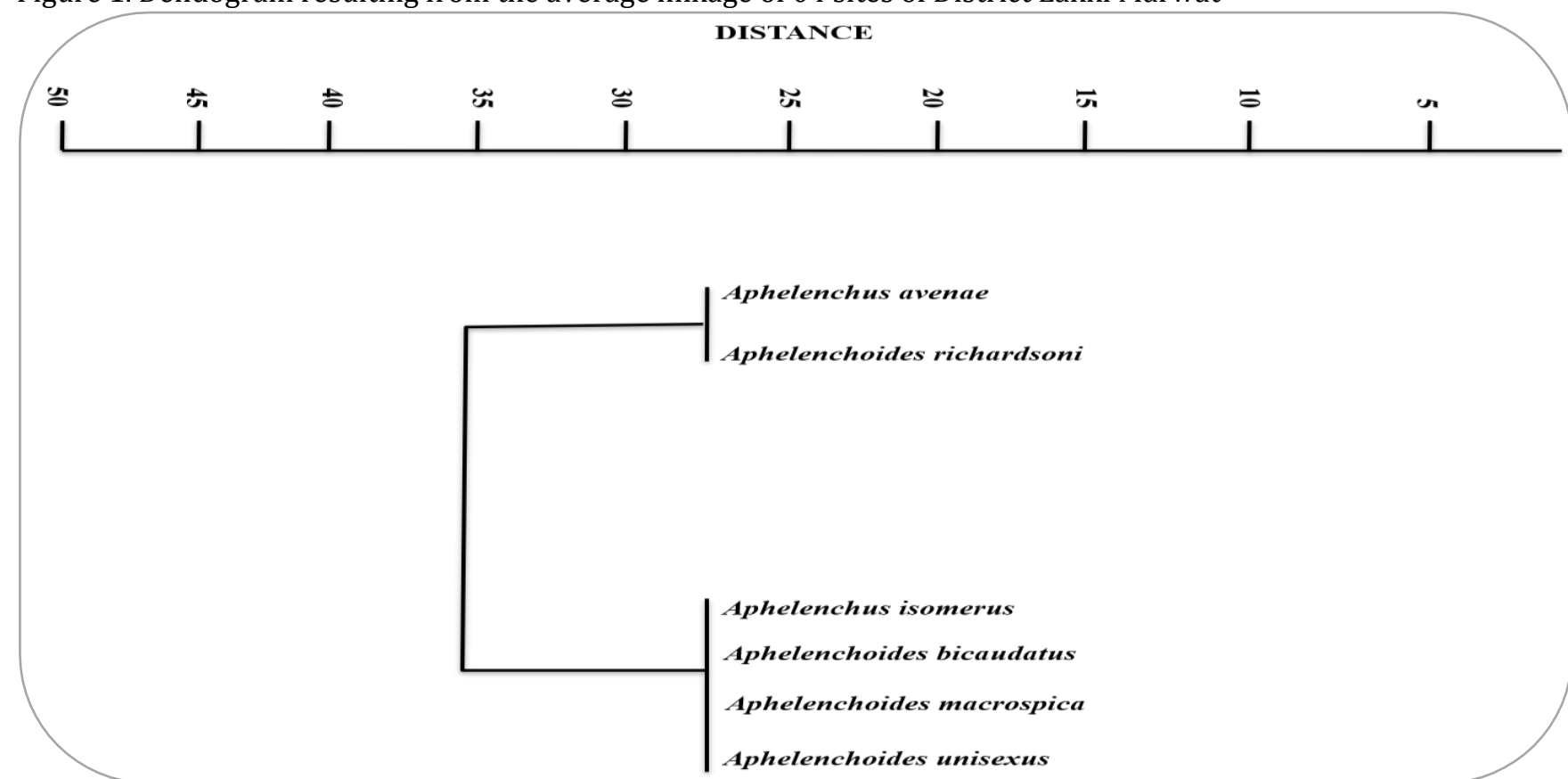

Figure 2. Dendogram resulting of cluster analysis of 06 species

Simpson Diversity Index: In the same context, diversity district Lakki Marwat is not quite stressful or more index was ensured in true letter and spirit on all four ecological niches. However, food webs in the areas are surveyed sites and resultantly all areas had relatively simple and do not contain any complexity of approximately similar diversity i.e. 0.50 as analyzed food. Absolutely, any change in the environment is more (Table 2). It has been assessed that environment of likely to be damaging the ecosystem.

Table 2. Simpson diversity index of nematode genus of four sites

\begin{tabular}{l|c}
\hline \multicolumn{2}{c}{ Simpson diversity index } \\
\hline Sites & Diversity Index \\
\hline Aba Khel & 0.5 \\
\hline Aghzar Khel & 0.5 \\
\hline Sarai Naurang & 0.5 \\
\hline Tajori & 0.5 \\
\hline $\begin{array}{l}\text { Composition of Aphelenchus and Aphelenchoides } \\
\text { species: During the study two species of Aphelenchus i.e. }\end{array}$ Anderson and Hooper, 1980 (Ebsary, 1991) and four
\end{tabular}


species of Aphelenchoides comprising Aphelenchoies bicaudatus (Imamura, 1931) Filipjev and Schuurmans Stekhoven, 1941, Aphelenchoides richardsoni (Grewal et al., 1992), Aphelenchoides unisexus (Jain and Singh, 1984) and Aphelenchoides macrospica (Golhasan et al., 2017) were identified. It is pertinent to mention herewith that the genus Seinura could not ascertained from district Lakki Marwat. The Aphelenchus avenae was found in highest frequency (40\%) from all areas, the second highest Aphelenchoides richardsoni (20\%) and followed by the lowest all remaining species(10\%)and the same also evaluated vide (Figure 3). All these species previously encountered from different areas of Pakistan; while current survey result showing presence of species (Table 3) and elaborates their area wise presence (Figure 4). Notably, Aphelenchoides macrospica was surfaced for the first time in Pakistan during the research work (Salma et al. 2020).

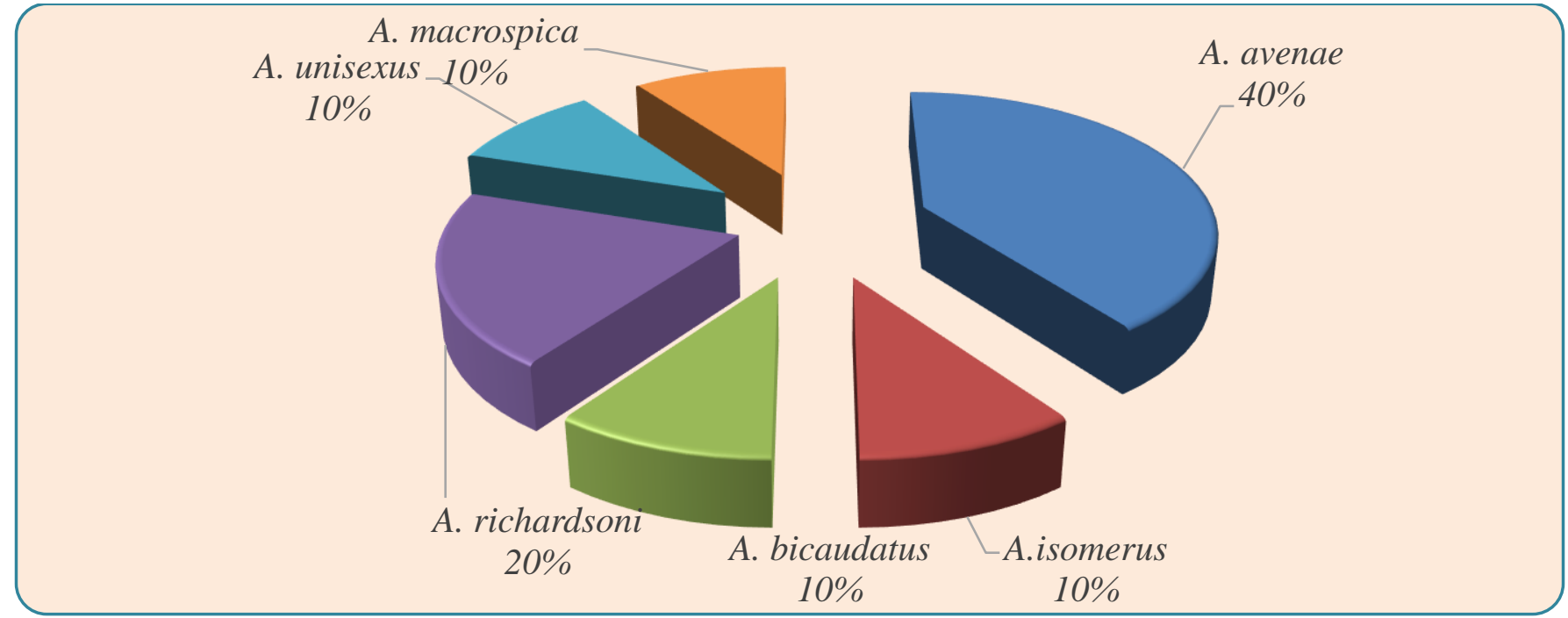

Figure 3. Occurrence percentage of species

Table 3. Species encountered during current survey according to new hosts and localities

\begin{tabular}{|c|c|c|c|}
\hline Nematodes & Hosts & Locations & First Description \\
\hline \multirow[t]{4}{*}{$\begin{array}{l}\text { Aphelenchus avenae } \\
\text { (Bastian, 1865) }\end{array}$} & Acacia nilotica (Kikar) & $\begin{array}{l}\text { Tajori, } \\
\text { Aghzar Khel }\end{array}$ & \multirow{4}{*}{$\begin{array}{l}\text { First time, it was surfaced from the } \\
\text { lower sheaths of oats leaves from } \\
\text { stubble field, Broadmoor, Berks, } \\
\text { England }\end{array}$} \\
\hline & Ziziphus mauritiana (Ber) & Tajori & \\
\hline & $\begin{array}{l}\text { Bougianvillea spectabilis } \\
\text { (Paper flower) }\end{array}$ & $\begin{array}{l}\text { Sarai } \\
\text { Naurang }\end{array}$ & \\
\hline & $\begin{array}{l}\text { Punica } \\
\text { granatum(Pomegranate) }\end{array}$ & Aba Khel & \\
\hline $\begin{array}{l}\text { Aphelenchusisomerus } \\
\text { Anderson and Hooper, } 1980 \\
\text { (Ebsary,1991) }\end{array}$ & $\begin{array}{l}\text { Citrus aurantium (Bitter } \\
\text { orange) }\end{array}$ & $\begin{array}{l}\text { Sarai } \\
\text { Naurang }\end{array}$ & $\begin{array}{l}\text { In the beginning, it was reported from } \\
\text { Cuba, associated with potatoes }\end{array}$ \\
\hline $\begin{array}{l}\text { Aphelenchoiesbicaudatus } \\
\text { (Imamura, 1931) Filipjev and } \\
\text { Schuurmans Stekhoven, } 1941\end{array}$ & Ziziphus mauritiana (Ber) & $\begin{array}{l}\text { Sarai } \\
\text { Naurang }\end{array}$ & $\begin{array}{l}\text { The said nematode was initially } \\
\text { retrieved from paddy field, Japan }\end{array}$ \\
\hline $\begin{array}{l}\text { Aphelenchoides macrospica* } \\
\text { (Golhasan et al., 2017) }\end{array}$ & $\begin{array}{l}\text { Bougianvillea } \\
\text { spectabilis(Paper flower) }\end{array}$ & $\begin{array}{l}\text { Sarai } \\
\text { Naurang }\end{array}$ & $\begin{array}{l}\text { Earlier it was associated with the } \\
\text { rhizosphere of rose plants in Hasanlou } \\
\text { old hill, Northwestern Iran }\end{array}$ \\
\hline $\begin{array}{l}\text { Aphelenchoides richardsoni } \\
\text { (Grewal, Siddiqi and Atkey, } \\
\text { 1992) }\end{array}$ & $\begin{array}{l}\text { Cicer aurantium (Bitter } \\
\text { orange) Bougianvillea } \\
\text { spectabilis (Paper flower) }\end{array}$ & $\begin{array}{l}\text { Sarai } \\
\text { NaurangSarai } \\
\text { Naurang }\end{array}$ & $\begin{array}{l}\text { Previously, the same was founded from } \\
\text { rhizosphere of mushroom, UK }\end{array}$ \\
\hline $\begin{array}{l}\text { Aphelenchoides unisexus(Jain } \\
\text { and Singh, 1984) }\end{array}$ & Ziziphus mauritiana (Ber) & $\begin{array}{l}\text { Sarai } \\
\text { Naurang }\end{array}$ & $\begin{array}{l}\text { At the earliest, it was obtained from soil } \\
\text { around the roots of Chrysanthemum } \\
\text { (Chrysanthemum spp) from Lucknow, India }\end{array}$ \\
\hline
\end{tabular}

Note:* New record 


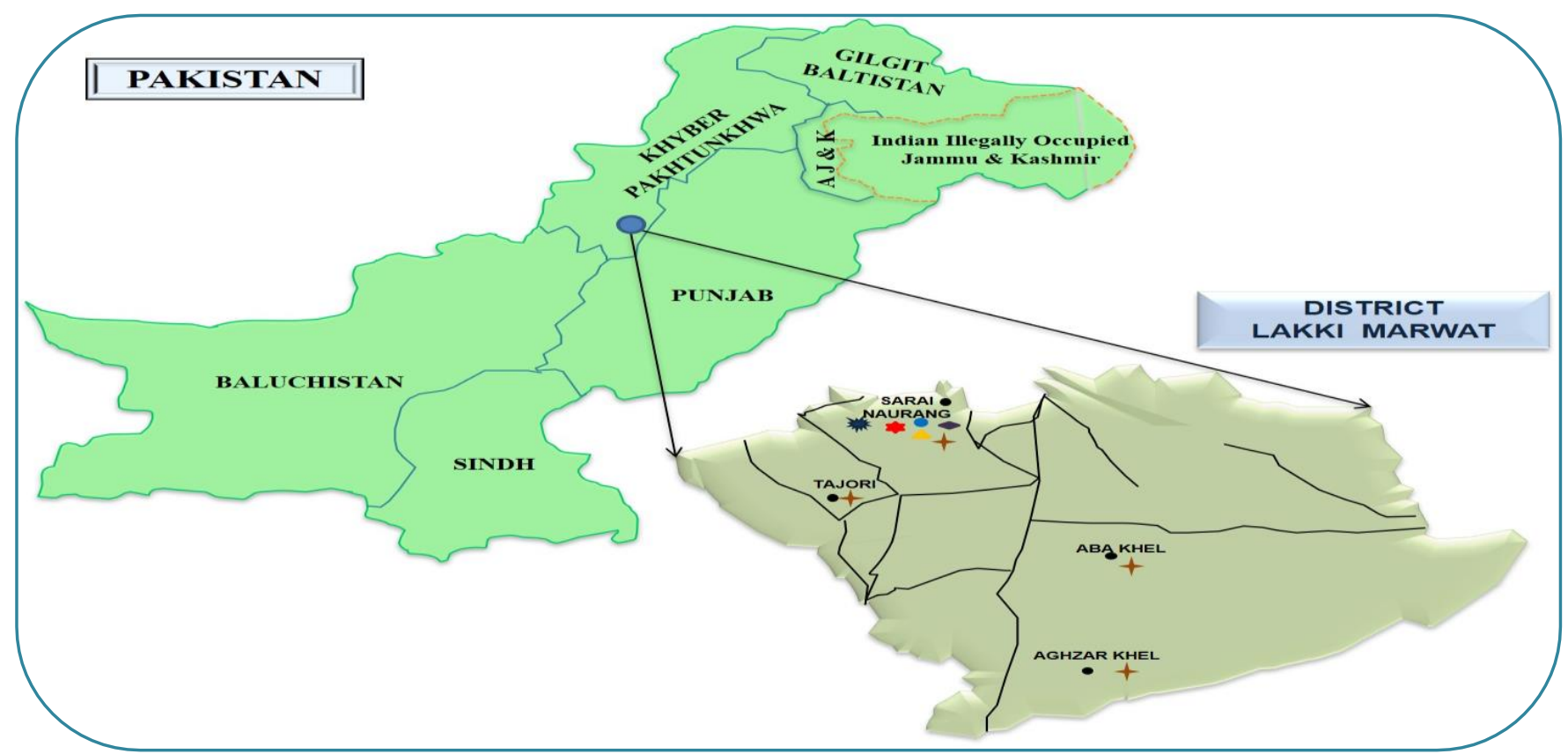

Figure 4. Species found from different locations of District Lakki Marwat, KPK, Pakistan

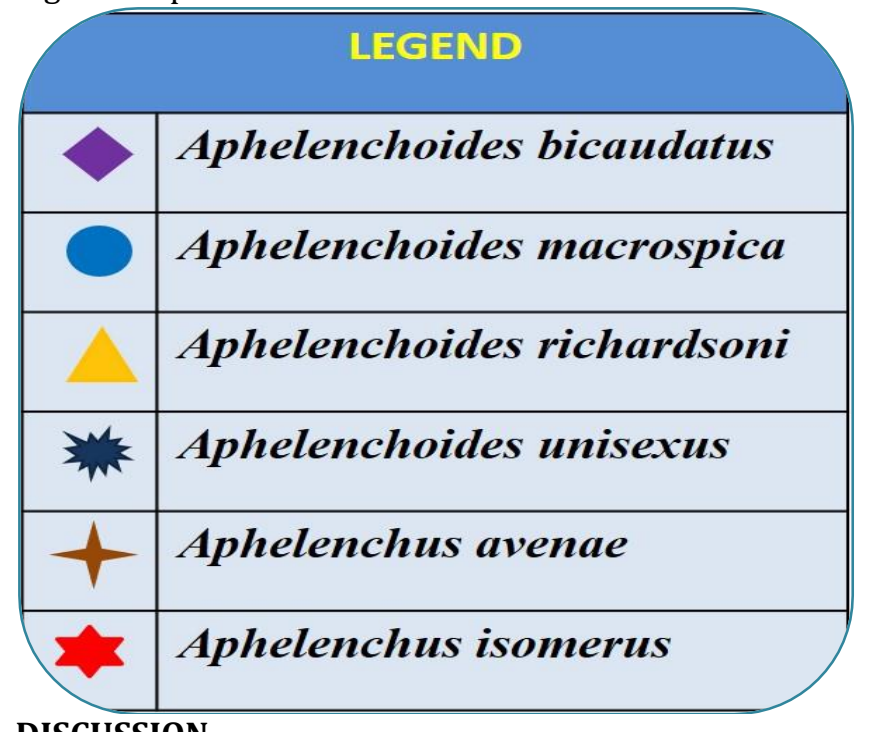

DISCUSSION

As per previous held record, earlier many species of Aphelenchus of the family Aphelenchidae(Fuchs, 1937) Steiner, 1949andAphelenchoides of the family Aphelenchoididae (Skarbilovich, 1947) Paramonov, 1953 were surfaced from case to case research work and accordingly published in several papers from time to time with respect to numerous hosts, locations and time period from Pakistan. Till to date most of the abundance occurrence species belonging to the family Aphelenchidae from Pakistan is Aphelenchus avenae (Bastian, 1865). The said species has already reported by Anwar and Sarwar, 1981; Gul and Saifullah, 1991 from sample of Citrus spp. collected from Sargodha,
Faisalabad, Sahiwal, Multan, Kalam, Mardan, Peshawar, Mansehra and Hazara. As well as by Khan et al., 2002 found around the root of Citrus trees and to evaluate its control by applying indigenous nematicides. Khan, 1991; Maqbool, 1992 from sample of lime collected from district Thatta. Khan and Bilqees, 1985 and Zahid, 2014 found in sample of date palm collected from district Thatta and district Khairpur respectively. Anwar et al., 1986; Maqbool, 1992; Gul and Khan, 2005 found in samples of sugarcane collected from Sargodha, Lahore, Faisalabad, Sahiwal and Charsadda. Gul and Saifullah, 1991; Maqbool, 1988; Saeed et al., 1986; Maqbool, 1986; Maqbool and Zaki, 1992; Maqbool, 1992; Aatika, 2015 from tobaco at Swat, Kalam, Mardan, Mansehra, Abbotabad, Charsada, Hazara, Rawalpindi, Islamabad, Gujrat, Lahore, Sheikhpura and Punjab. Gul and Saifullah, 1991; Qasim and Ahmed, 1989; Maqbool, 1988; Maqbool, 1986; Maqbool and Zaki, 1992; Maqbool, 1992; Khan and Hussain, 2004; Bhutta, 2008; Aatika, 2015 from potato samples collected from various places including Hunza, Kalam, Peshawar, Kaghan Valley, Bannu, D I Khan, Mansehra, Abbotabad, Hazara, Gujrat, Gujranwala, Faisalabad, Therparker, Hyderabad, Thatta, Karachi, Northern areas and Punjab. Solangi, 1981 found Aphelenchus and Aphelenchoides population in different region of district Hyderabad on the basis of symptoms appearance. Gul and Saifullah, 1991; Maqbool, 1988; Maqbool, 1992; Aatika, 2015 from maize sample collected from Kalam, Peshawar, Mansehra, Abbotabad, 
Hazara, Sargodha, Mianwali, Sibbi, Chagi, Nawab Shah, Hyderabad, Thatta and Punjab. Maqbool, 1988 and Maqbool, 1992; Aatika, 2015 from sample of wheat collected from Sailkot, Gujranwala, Sheikhupura, Bahawalpur, Rahim Yar Khan, Sukkar, Nawab Shah, Hyderabad and Punjab. Aatika, 2015 found in sample of sorghum collected from Punjab. Maqbool, 1988; Maqbool, 1992 from grapes sample retrieved from Quetta, Pishin and Chagi. Islam et al., 1994; 1996 from sample of apple retrieved from Sawat. Khan and Bilqees, 1994; Khan and Shaukat, 1999; Maqbool, 1988; Maqbool, 1992 from rice sample collected from Bajore Agency, Thatta, Larkana, Nawab Shah and Sanghar. Nematode community of Aphelenchus avenae associated with two rice varieties namely Lateefy and Kharai Ganja were investigated in district Thatta by Khan et al., 2000 . Khan et al., 1998 studied the effect of neem cake, neem seed coat and carbofuran on the population density of four nematodes including Helicotylenchus indicus, Merlinus brevidence, Aphelenchus avenae and Meleidogyne Sp. larvae from garlic. Khan et al., 2007; Khan, 2008 from sample of papaya collected from Karachi and Hyderabad. Khan, 2008 from sample of mango collected from Karachi and Hyderabad. Brown, 1962 described Aphelenchus sp from sample of chilli collected from Malir, Karachi, while Khan et al., 2000; Anwar et al., 2013 and Zarina et al., 2015; Aatika, 2015 reported from sample of chilli collected from lower Sindh, Faisalabad, Jhang, Kasur, Lahore, Nawab Shah, Sargodha, T.T. Singh, Sheikhupura, Karachi and Punjab. Nasira et al., 2008 from sample of Ashok tree due to cause of great damages to the tree at Karachi. Anwar et al., 2013 found from sample of tomato collected from Faisalabad, Jhang, Kasur, Lahore, Nawab Shah, Sargodha, $\mathrm{T}$ T Singh and Sheikhupura as well as by Samina and Erum, 2019 from Kurrum Agency. Nadia, 2019 from walnut sample collected from Hazara Division. Anwar et al., 2013 from cucumber sample collected from Faisalabad, Jhang, Kasur, Lahore, Nawab Shah, Sargodha, T T Singh, Sheikhupura. Anwar et al., 2013 from sample of bell peppers collected from Faisalabad, Jhang, Kasur, Lahore, Nawab Shah, Sargodha, T T Singh, Sheikhupura. Israr, 2017 reported from radish, turnip and carrot samples collected from KPK and Sindh while on radish, turnip, carrot and sugar beet sample from Punjab. Tariq, 2013 reported Aphelenchus avenae from sample of different medicinal plants including kachnar, jungli badam, aloe, lemongrass, basil, sukhchain and castor collected from Karachi, Thatta and Hyderabad region. Similary, Aphelenchus isomerus Anderson and Hooper, 1980 (Ebsary, 1991) by Akhter and Zarina, 2014 found from chilli sample collected from Karachi. In the same way Aphelenchoides bicaudatus (Imamura, 1931) Filipjev and Schuurmans Stekhoven, 1941 by Maqbool, 1986; 1988; 1990; 1992; Maqbool and Zaki, 1992 from sample of rice, kidney bean, pearl millet, sugarcane and maize collected from Sukkar, Nawab Shah, Thatta, Sanghar, Larkana, Dadu, Badin and Khairpur. Shahina and Maqbool, 1992 from sample of banana collected from Sukkar, Nawab Shah and Thatta. Mussarat, 2011 reported Aphelenchus bicaudatus from sample of rice and soybean collected from Faisalabad, Multan, Raheem Yar Khan, Sanghar, Badin and Dir. Israr et al., 2017 from sample of radish, turnip and carrot collected from Faisalabad, Tando Allahyar, Swat, Sargodha, Dadu, Peshawar, Sialkot, Badin and D. I Khan. Accordingly, in the same context, Aphelenchoides richardsoni) Grewal et al., 1992) from pumpkin and Aphelenchoides unisexus (Jain and Singh, 1984) from tomato sample by Samina and Erum, 2019 collected from Kurram Agency. These genera have been causing serious damages to the root hairs and epidermal tissues which resultantly minimize the capability of roots to sucks water and nutrient from the nearby soil (Endo, 1975).

Notwithstanding above, the research work was carried out with an aim to get maximum information about presence of nematodes especially Order Aphelenchida in those areas where no research work has been carried out yet. The presence of new recorded species Aphelenchoides macrospica is an indicator of existence of other undiscovered species. Further research work in other parts of Pakistan will surely be helpful in identifying additional species of nematodes of Aphelenchida. The evidence on nematodes occurrence may be assisted the formers for planning and directing nematode management policies to handle the nematodes population below their threshold levels.

\section{REFERENCES}

Aatika, S. 2015. Biodiversity and community analysis of nematode fauna of maize and other crops from Adjoining areas of maize fields from Punjab, Pakistan. M. Phil. Thesis, National Nematological Research Centre, University of Karachi, Pp. 126.

Akhter, S. and B. Zarina. 2014. Bitylenchus capsicumi sp. n. and one known species of the genus Aphelenchus from chilli plants in Sindh, Pakistan. International 
Journal of Biological Research, 2: 135-141.

Anderson, R. and D. Hooper. 1980. Diagnostic value of vagina structure in the taxonomy of Aphelenchus Bastian, 1865 (Nematoda: Aphelenchidae) with a description of A (Anaphelenchus) isomerus $\mathrm{n}$. subgen., n. sp. Canadian Journal of Zoology, 58: 924928.

Anwar, S. A., M. A. Kallu, M. A. Javid and S. H. Khan. 1986. Nematode parasites of sugarcane. Journal of Agriculture Research Pakistan, 24: 123-127.

Anwar, S. A., M. Mahdi, M. McKenry and A. Qadir. 2013. Survey of plant-parasitic nematodes associated with four vegetable crops cultivated within tunnels. Pakistan Journal of Zoology, 45: 595-603.

Anwar, S. and M. Sarwar. 1981. Nematodes associated with citrus roots and rhizosphere in the Punjab. Journal of Agricultural Research: 141-146

Baermann, G. 1917. Eine einfache methode zur auffindung von Ancylostomum (Nematoden) larven in erdproben. Geneeskd Tijdschr Ned Indie, 57: 131137.

Bastian, H. C. 1865. II. Monograph on the Anguillulidæ, or Free Nematodes, Marine, Land, and Freshwater; with Descriptions of 100 New Species. Transactions of the Linnean Society of London, 25: 73-184.

Bhutta, A. 2008. Survey of tuber borne diseases of potato in Northern Areas, Pakistan. Pakistan Journal of Phytopathology, 20: 20-33.

Brown, K. 1962. A survey of some plant parasitic nematode problems in Pakistan. Shell International Chemical Company Co. Ltd, pp 9

Cobb, N. A. 1918. Estimating the nema population of soil, with special reference to the sugar-beet and rootgall nemas, Heterodera schachtii Schmidt and Heterodera radicicola (Greef) Müller: and with a description of Tylencholaimus aequalis $\mathrm{n}$. sp. US Government Printing Office.1:48 Pp.

Courtney, W. D., D. Polley and V. Miller. 1955. TAF, an improved fixative in nematode technique. Plant Disease Reporter, 39: 570-571.

De Man, J. G. 1884. Die, frei in der reinen Erde und im süssen Wasser lebenden Nematoden der Niederländischen Fauna: eine systematischfaunistische Monographie. EJ Brill.Pp. 1-206.

Endo, B. 1975. Pathogenesis of nematode-infected plants. Annual Review of Phytopathology, 13: 213-238.

ESA, 2012. Khyber Pakhtunkhwa-Southern Area Development Project (KP-SADP) Dera Ismail Khan,
Lakki Marwat and Tank Districts, Government of Khyber Pakhtunkhwa.

Filipjev, I. N. and J. H. Schuurmans Stekhoven. 1941. A Manual of Agricultural Helminthology. E. J. Brill, Leiden, Holland.

Fischer, M. 1894. "Ubereine Clematis-Krankheit. Ber. Physiol. Lab. Landw. Inst. Halle 3: 1-11.

Fuchs, A. G. 1937. Neue parasitische und halbparasifische Nematoden bei Borkenkafern und einige andere Nematoden. I. Tell. Zool. Jahrb., Abt. Syst. Okol. Geogr. Tiere, 70: 291-380.

Golhasan, B., R. Heydari, M. Esmaeili and E. Miraeiz. 2017. Description of Aphelenchoides macrospica $n$. sp.(Nematoda: Aphelenchoididae) from northwestern Iran. Journal of Nematology, 49: 67.

Grewal, P., M. Siddiqi and P. Atkey. 1991. Aphelenchoides richardsoni sp. nov. and Seinura paynei sp. nov. from mushrooms in the British Isles and S. obscura sp. nov. from India (Nematoda: Aphelenchina). AfroAsian Journal of Nematology, 1: 204-211.

Gul, F. and P. Khan. 2005. Assessment of plant parasitic nematodes associated with sugarcane crop in district Charsadda, NWFP Province. In: Shahina, F., K. Firoza and M. H. Soomro (Eds.). Proc. $5^{\text {th }}$ National Nematology Conference., Pakistan Journal of Nematology, 23: 51-56.

Haq, I. 2009. An analysis of Paradigm shift from public extension to public private partnership extension system in NWFP, Pakistan. PhD thesis, University of Agriculture, Faisalabad-Pakistan.

Hunt, D. J. 1993. Aphelenchida, Longidoridae and Trichodoridae: Their systematics and bionomics. CAB International, pp 372.

Imamura, S. 1931. Nematodes in the paddy field, with notes on their population before and after irrigation. Journal of College of Agriculture, Imperial University of Tokyo, 11: 193-240.

Islam, S., A. Khan and F. Bilqees. 1994. Nematodes associated with apple trees in Swat, NWFP, Pakistan. Proceedings of Pakistan Congress of Zoology, 14: 317-320.

Islam, S., A. Khan and F. Bilqees. 1996. Survey of styletbearing nematodes associated with apple (Malus pumila mill.) in swat district, NWFP, Pakistan. Proceedings of Parasitology, 21: 1-9.

Israr, M., F. Shahina and K. Nasira. 2017. Description of Aphelenchoides turnipi n. sp. and redescription of A. siddiqii with notes on A. bicaudatus (Nematoda: 
Aphelenchoididae) from Pakistan. Pakistan Journal of Nematology, 35: 3-12.

Israr, M., F. Shahina and M. Habib. 2018. Impact of nematode infestation on nutritional quality of some underground vegetables in Pakistan. Pakistan Journal of Nematology, 36: 217.

Jain, V. and S. Singh. 1984. Two new species of Aphelenchoides (Nematoda: Aphelenchoididae) from India. Bulletin of Entomology, 25: 135-142.

Kanzaki, N. and R. Giblin-Davis. 2012. Aphelenchoidea. Practical plant nematology. Jalisco, Mexico, Colegio de Postgraduados and Mundi-Prensa, Biblioteca Básica de Agricultura, pp 161-208.

Keshari, A. K., B. Hari, A. H. Bhat and M. Shah. 2019. Prospects and present status and of Entomopathogenic Nematodes (Steinernematidae and Heterorhabditidae) in Nepal. Journal of Applied and Advanced Research, 4: 30-35.

Khan, A. 1991. Nematological survey of lemon plantation in Thatta District, Sindh, Pakistan. Current Nematology, 2: 7-8.

Khan, A. and F. Bilqees. 1985. Stylet bearing nematodes associated with datepalm (Phoenix dactylifera Linn.) in Thatta district. Pakistan Journal of Zoology, 17: 299-300.

Khan, A. and F. M. Bilqees. 1994. Pant parasitic nematodes association with paddy crop in Bajore Agency, Pakistan. In: Ahmed, M. and A. R. Shakoori (Eds). Proc.12 th Pakistan Congress of Zoology, 12: 1-3.

Khan, A. and S. Shukat. 1999. Survey of stylet bearing nematodes associated with rice (Oryza sativa L.) in Thatta district, Sindh, (Pakistan). Sarhad Journal of Agriculture, 15: 221-225

Khan, A., F. Qamar and S. Shaukat. 1998. Relative nematicidal activity of neem seed coat and neem cake against nematodes associated with garlic. Bulletin in Pure and Applied Science, 17: 5-7.

Khan, A., M. Sayed and S. S. Shaukat. 2007. Nematodes associated with papaya in Sindh (Pakistan). Sarhad Journal of Agriculture, 23: 145-147.

Khan, A., S. S. Shaukat and H. Fatima. 2000. A comparative study of nematode communities associated with two rice varieties in Thatta District, Sindh, Pakistan. Science Khyber, 13: 33- 38.

Khan, A., S. Shauket and I. Ahmad. 2000. Nematode communities associated with chilies in lower Sindh, Pakistan. Pakistan Journal of Biological Sciences, 3: 457- 458.
Khan, M. and A. Hussain. 2004. Plant parasitic nematodes in seed potato crop of northern areas of Pakistan. International Journal of Biology and Biotechnology, 1: 365-367.

Khan, S. M. 2008.Control of the mango (Mangiferaindica L.) and papaya (Carica papaya L.) associated nematodes using plant extracts. Ph. D. Thesis, Department of Zoology, University of Karachi, Karachi, Pakistan, Pp. 109.

Khan, S., F. Qamar, H. Khan, A. Shah and Y. Rizki. 2002. Intensity of phytonematodes in citrus orchards of North West Frontier Province and their control through indigenous nematicides. Pakistan Journal of Scientific and Industrial Research, 45: 130-132.

Khusainov, R. 2013. Aphelenchoides eximius sp. n. (Aphelenchina: Aphelenchoididae) from the Central Part of European Russia. International Journal of Nematology, 23: 43-48.

Maqbool, M. 1988. An overview of nematode problem and research in Pakistan. US-Pakistan International Workshop on Plant Nematology, Karachi (Pakistan), 6-8 Apr 1986. NNRC.

Maqbool, M. 1988. An overview of nematode problem and research in Pakistan. US-Pakistan International Workshop on Plant Nematology, Karachi (Pakistan), 6-8 Apr 1986. NNRC.

Maqbool, M. A. 1986. Classification and distribution of plant parasitic nematodes in Pakistan.

Maqbool, M. A., B. Zarina, K. Nasira and K. Firoza. 1992. Distribution and host association of plant parasitic nematodes in Pakistan. Distribution and host association of plant parasitic nematodes in Pakistan.

Mussarat, R. 2011. Genetic diversity of resistant and susceptible rice and soybean cultivars with reference to root-knot nematodes, Ph.D. Thesis, Department of Botany, National Nematological Research Centre, University of Karachi, Pp.307.

Nasira, K., F. Shahina and K. Saifullah. 2008. Control of Pratylenchus coffeae root-lesion nematode in ashok tree using chemical amendment. Pakistan Journal of Nematology, 26: 175-186.

Nickle, W. R. 1970. A taxonomic review of the genera of the Aphelenchoidea (Fuchs, 1937) Thorne, 1949 (Nematoda: Tylenchida). Journal of Nematology, 2: 375-392.

Paramonov, A. 1953. Revision of the super family Aphelenchoidea Fuchs, 1937 Revision of the super 
family Aphelenchoidea Fuchs, 1937 (Nematoda: Tylenchata) Papers on helminthology presented to Academician K.I. Skryabin for his $75^{\text {th }}$ birthday, Moskva, Izdat'stvo Akad. Nauk. SSSR, Pp.488-496

Qasim, M. and S. Ahmed. 1989. Plant-parasitic nematodes and potato seed production in the northern areas of Pakistan. International nematology network newsletter, 6: 43-44.

Saeed, M., S. Khan and F. Qamar. 1986. A survey of the nematode problem of tobacco in Pakistan. A. Nurseries. Pakistan Journal of Scientific and Industrial Research, 29: 279-283.

Saeed, N. 2019. Pathogenecity and control of nematodes with Walnut in Hazara Division. Hazara University, Mansehra.

Samina, S. and Y. Erum. 2019. Nematode fauna of Kurram Agency, Pakistan. Pakistan Journal of Nematology, 37: 1-20.

Sánchez Monge, G. A., L. Flores, L. Salazar, S. Hocland and W. Bert. 2015. An updated list of the plants associated with plant-parasitic Aphelenchoides (Nematoda: Aphelenchoididae) and its implications for plant-parasitism within this genus, 4013:207224.

Seinhorst, J. 1959. A rapid method for the transfer of nematodes from fixative to anhydrous glycerin. Nematological, 4: 67-69.

Shahina, F. and M. Maqbool. 1992. Nematodes from banana fields in Sindh with morphometric data on nine species with six representing new records of occurrence in Pakistan. Pakistan Journal of
Nematology, 10: 23-39.

Shahina, F., K. Nasira, K. Firoza and Y. Erum. 2019. Overview of the nematode fauna of Pakistan. Pakistan Journal of Nematology, 37: 171-243.

Simpson, E. H. 1949. Measurement of diversity. Nature, 163: 688-688.

Skarbilovich, T. S. 1947. [Revision of the systematics of the nematode family Anguillulinidae Baylis and Daubney, 1926]. Doklady Akademii Nauk SSR 57, 307-308 (in Russian).

Solangi, G. 1981. General survey and identification of nematode diseases in Sindh region. Journal of agricultural research, 19: 181-188.

Soomro, M., A. Monir and A. Ahmad. 1997. Prevalence of plant parasitic nematodes in Potato fields of Pakistan. Crop Diseases Research Institute. PARC Islamabad Pakistan: 130-139.

Steiner, G. 1949. Plant nematodes the grower should know. Proceedings. Soil Science Society of Florida. pp. 72-117.

Zahid, G. 2014. Phylogenic studies of date palm nematodes in district khairpur, Sindh, Pakistan, $\mathrm{Ph}$. D. Thesis, Department of botany, National nematological research centre, University of Karachi, Pp. 130.

Zaki, M. J. and M. A. Maqbool. 1992. Annotated bibliography on plant nematology in Pakistan, 1947-1992.

Zarina, B., S. Akhtar and D. Khan. 2015. The nematodes of chilli plants of Sindh: Abundance, diversity and the assemblage. FUUAST Journal of Biology, 5: 71-92.

\section{Contribution of Authors:}

Samreen Khan

Salma Javed

Tabassum A. Khanum
: Executed survey, collected the data and wrote the manuscript

: Supervised the research and reviewed the manuscript

: Analyzed the data. All authors read and approved the final manuscript 